Homepage: https://ojs.stiem-bongaya.ac.id/index.php/BJRA

\title{
Pengaruh Karakteristik Pemerintah Daerah dan Hasil Pemeriksaan Audit BPK Terhadap Kinerja Keuangan
}

\author{
Annas L. Mappiasse ${ }^{1)}$ \\ Email: annas.lalo@stiem-bongaya.ac.id
}

\author{
${ }^{1}$ Dosen Prodi Akuntansi, STIEM Bongaya Makassar
}

(Diterima: 1 Juli 2018; di revisi: 28 Agustus-2018; dipublikasikan: 31 Oktober-2018)

\begin{abstract}
:
This research is related to the issue performance of local government in Indonesia, which needs to be improved after the introduction of regional autonomy. Each of local governments need to establish and manage their own public financial management system. Many factors may affect the financial performance of local government. This study aimed to examine whether the characteristics of the local governments and the results of the audit can improve the financial performance of local government, as measured by the efficiency ratio. By using multiple regression analysis on 94 samples of local government financial report for year 2011, the study was able to prove that the dependence level and government expenditures have positive significant effect on financial performance. Legislative and the audit findings have negative significant effect on financial performance. While the size, wealth, and audit opinions do not affect the financial performance of the government in the island of Java.
\end{abstract}

Keywords: Audit, characteristics of local governments, financial performance

\section{PENDAHULUAN}

Undang-Undang Republik Indonesia Nomor 32 Tahun 2004 tentang Pemerintahan Daerah menyatakan bahwa efisiensi dan efektivitas penyelenggaraan pemerintah daerah perlu ditingkatkan dengan lebih memperhatikan aspekaspek hubungan antar susunan pemerintahan dan antar pemerintahan daerah, potensi dan keanekaragaman daerah, peluang dan tantangan persaingan global dengan memberikan kewenangan yang seluas-luasnya kepada daerah disertai dengan pemberian hak dan kewajiban menyelenggarakan otonomi daerah dalam kesatuan sistem penyelenggaraan pemerintah negara. Oleh karena itu pemerintah daerah harus mampu menyelenggarakan pemerintahannya agar tercipta tata kelola pemerintahan daerah yang baik. Sistem evaluasi, monitoring, dan pengukuran kinerja yang sistematis guna mengukur kemajuan yang dicapai pemerintah daerah dalam kurun waktu tertentu juga perlu diterapkan.

Berdasarkan penelitian-penelitian terdahulu, Penelitian yang dilakukan Suhardjanto, (2011) meneliti tentang pengaruh karakteristik pemerintah daerah terhadap kepatuhan pengungkapan wajib dalam laporan keuangan pemerintah daerah.Penelitian tersebut menggunakan variabel ukuran daerah (size), jumlah Satuan Kerja Perangkat Daerah (SKPD), dan Status Daerah untuk memproksikan karakteristik pemerintah daerah.Penelitian Mustikarini dan Fitriasari (2012) menggunakan ukuran daerah (size), tingkat kekayaan daerah, 
tingkat ketergantungan pada pemerintah pusat, dan belanja daerah dalam menjelaskan karakteristik pemerintah daerah.

Selain karakteristik pemerintah daerah, peneliti menggunakan variabel hasil pemeriksaan audit BPK dalam mengukur keterkaitan dengan kinerja keuangan pemerintah daerah.Hal tersebut diperlukan untuk menghindari adanya berbagai macam tindak kecurangan dalam pelaksanaan kegiatan pemerintahan. Berdasarkan UndangUndang Republik Indonesia Nomor 15 Tahun 2004 tentang Pemeriksaan Pengelolaan dan Tanggung Jawab Keuangan Negara menyebutkan bahwa pemeriksaan adalah proses identifikasi masalah, analisis, dan evaluasi yang dilakukan secara independen, obyektif, dan profesional berdasarkan standar pemeriksaan, untuk menilai kebenaran, kecermatan, kredibilitas, dan keandalan informasi mengenai pengelolaan dan tanggung jawab keuangan negara. Hasil pemeriksaan keuangan yang dilakukan oleh Badan Pemeriksa Keuangan (BPK) dapat berupa temuan audit, opini audit maupun kesimpulan audit.Penelitian mengenai hasil audit BPK telah dilakukan oleh Mustikarini dan Fitriasari (2012) yang menggunakan temuan audit BPK dalam menjelaskan hasil audit. Penelitian Virgasari (2009) dan Indrarti (2011) menggunakan opini audit dalam menjelaskan hasil audit BPK. Berdasarkan penelitian tersebut, peneliti menggunakan variabel temuan audit BPK dan opini audit BPK dalam memproksikan hasil pemeriksaan audit.

Berdasarkan pemaparan di atas, maka dilakukan penelitian dengan tujuan untuk mengetahui dan menganalisis pengaruh Ukuran pemerintah daerah, Ukuran pemerintah daerah, Tingkat ketergantungan pada pemerintah pusat, belanja modal, Ukuran legislatif, Temuan audit dan opini audit terhadap kinerja keuangan pemerintah daerah.

\section{METODE}

\section{Pendekatan Penelitian}

Pendekatan penelitian yang digunakan dalam penelitian ini adalah pendekatan deskriptif kuantitatif. Santoso (2012) menjelaskan pendekatan deskriptif kuantitatif merupakan penelitian dengan mendeskripsikan secara sistematis, faktual dan akurat terhadap kondisi dan fenomena yang terjadi berdasarkan data dan informasi yang didapatkan dalam penelitian. Dalam penelitian ini, digunakan metode kuantitatif karena angka, mulai dari pengumpulan data, penafsiran data tersebut, serta menampilkan hasilnya. Selain itu juga akan digunakan tabel, grafik dan diagram.

\section{Populasi dan Sampel}

Dalam penelitian ini sampel diambil dengan cara purposive sampling, yang berarti sampel diambil berdasarkan kriteria tertentu sesuai dengan tujuan penelitian (Sekaran dan Bougie, 2010). Kriteria tersebut yaitu: sampel adalah pemerintah daerah kabupaten/kota yang memiliki semua data laporan keuangan yang lengkap meliputi Neraca dan Laporan Realisasi Anggaran (LRA) yang telah diaudit oleh BPK; sampel memiliki data laporan hasil pemeriksaan audit BPK tahun 2014 untuk mendapatkan jumlah temuan audit dan opini audit yang diambil dari Ikhtisar Pemeriksaan tahun 2014 dan sampel yang terdapat data-data nonkeuangan seperti jumlah anggota legislatif, yang didapatkan dari situs resmi masing-masing pemerintah daerah di Sulawesi Selatan sebanyak 24 Kabupaten.

Metode Pengumpulan Data 
Dalam penelitian ini data dikumpulkan dengan mengambil data pada situs resmi pemerintah daerah di Sulawesi Selatan.

\section{Definisi Operasional}

Definisi operasional masing-masing variabel secara rinci dapat dilihat dalam tabel 1 sebagai berikut :

\section{Tabel 1. Definisi Operasional}

\begin{tabular}{|l|l|l|}
\hline $\begin{array}{l}\text { Independen } \\
(\text { X): Karakte } \\
\begin{array}{l}\text { Ristik } \\
\text { Pemerintah } \\
\text { Daerah }\end{array}\end{array}$ & $\begin{array}{l}\text { X1: } \\
\text { Ukuran } \\
\text { Pemerintah } \\
\text { Daerah }\end{array}$ & $\begin{array}{l}\text { Total Aset } \\
\text { Pemerintah Daerah }\end{array}$ \\
\hline & $\begin{array}{l}\text { X2: } \\
\text { Tingkat }\end{array}$ & $\begin{array}{l}\text { Total Pendapatan } \\
\text { Asli Daerah (PAD) }\end{array}$ \\
\hline & $\begin{array}{l}\text { X3: Tingkat } \\
\text { Ketergantungan }\end{array}$ & $\begin{array}{l}\text { Total Dana } \\
\text { Alokasi Umum }\end{array}$ \\
\hline & X4: Belanja & Total Realisasi \\
\hline & $\begin{array}{l}\text { X5: Ukuran } \\
\text { Legislatif }\end{array}$ & $\begin{array}{l}\text { Jumlah Anggota } \\
\text { Dewan }\end{array}$ \\
\hline $\begin{array}{l}\text { Hasil } \\
\text { Pemeriksaan }\end{array}$ & $\begin{array}{l}\text { X6: Temuan } \\
\text { Audit BPK }\end{array}$ & $\begin{array}{l}\text { Temuan audit (dalam } \\
\text { rupiah) }\end{array}$ \\
\hline & X7: Opini Audit & Opini Audit \\
\hline $\begin{array}{l}\text { Dependen } \\
\text { (Y): Kinerja } \\
\text { Keuangan }\end{array}$ & & $\begin{array}{l}\text { Realisasi } \\
\text { Pengeluaran } \\
\text { (output) terhadap }\end{array}$ \\
\hline
\end{tabular}

\section{Metode Analisis Data}

Untuk menguji hubungan antara variabel independen dan variabel dependen dalam penelitian ini maka dilakukan analisis linier berganda melalui alat analisis program SPSS. Model Persamaan regresi linier berganda adalah sebagai berikut :

$$
\begin{aligned}
& \mathrm{Y}=\alpha+\beta 1 \mathrm{X} 1+\beta 2 \mathrm{X} 2+\beta 3 \mathrm{X} 3+\beta 4 \mathrm{X} 4+\beta 5 \mathrm{X} 5 \\
& +\beta 6 \mathrm{X} 6+\beta 7 \mathrm{X} 7+\mathrm{e}
\end{aligned}
$$

Keterangan :

Y : Kinerja Keuangan Pemda

X1 : Ukuran Pemerintah Daerah

$\mathrm{X} 2$ : Tingkat kekayaan daerah

X3 : Tingkat ketergantungan pada

pemerintah pusat

X4 : Belanja daerah

X5 : Ukuran legislatif

X6 : Temuan audit BPK

$\mathrm{X} 7$ : Opini audit BPK $\alpha$ : Konstanta.

$\beta$ : Koefisien Regresi.

e : Error.

\section{HASIL DAN PEMBAHASAN}

Hasil analisis dalam penelitian ini dapat dilihat pada tabel 2 sebagai berikut :

Tabel 2. Hasil Uji Regresi

\begin{tabular}{|l|c|c|l|}
\hline Variabel & Koefisien & T & Sig. \\
\hline Konstanta & 0,720 & 7,311 & 0,000 \\
\hline Ln TA & $-0,014$ & $-1,461$ & 0,148 \\
\hline PAD & $-0,104$ & $-1,303$ & 0,196 \\
\hline DAU & 0,158 & 3,431 & 0,001 \\
\hline Ln BD & 0,042 & 2,257 & 0,027 \\
\hline DPRD & 0,000 & $-1,165$ & 0,247 \\
\hline Ln_Temuan & $-0,004$ & $-1,959$ & 0,053 \\
\hline Opini & $-0,007$ & $-1,634$ & 0,106 \\
\hline Tipe_PemDa & 0,025 & 2.043 & 0,044 \\
\hline
\end{tabular}

Sumber : Output SPSS, 2018

Hasil penelitian menunjukkan Ukuran pemerintah daerah; tingkat kekayaan daerah; dan opini audit tidak berpengaruh signifikan terhadap kinerja keuangan pemerintah daerah di Sulsel. Sedangkan tingkatketergantungan pada pemerintah pusat dan jumlah belanja daerah berpengaruh positif signifikan terhadap kinerja keuangan pemerintah daerah, serta ukuran legislatif dan temuan audit berpengaruh negatif signifikan terhadap kinerja keuangan pemerintah daerah di Sulsel.

1. Pemerintah daerah dengan aset dan kekayaan (PAD) yang besar seharusnya mampu memberikan kinerja yang baik. Jika pemerintah daerah dengan aset dan kekayaan yang besar namun kinerja efisiensinya dinilai masih buruk maka pemerintah daerah tersebut harus instropeksi dan melakukan perbaikan ke depannya. Karena logikanya pemerintah daerah dengan aset dan kekayaan 
yang besar pasti memiliki tekanan yang lebih besar pula dari masyarakat untuk lebih baik dalam mengelola dan menggunakan segala sumber daya yang dimilikinya itu guna perbaikan kinerja.

2. Pemerintah daerah dengan tingkat ketergantungan pada pemerintah pusat ratarata masih memiliki persentase yang sangat besar. Hasil ini seharusnya mampu menjadikan suatu tekanan bagi pemerintah daerah bahwa dalam pelaksanaan pemerintahan mereka akanselalu diawasi oleh pemerintah pusat sehingga mampu memberikan kinerja yang baik pula.

3. Pemerintah daerah dengan total belanja yang besar seharusnya mampu memberikan kinerja yang baik. Karena belanja daerah baik itu yang sifatnya rutin maupun belanja modal dan infrastruktur dapat meningkatkan kinerja pemerintah daerah kepada masyarakat. Pemerintah daerah tentunya dituntut harus mampu untuk mengelola pengeluaran-pengeluaran yang dapat meningkatkan kinerjanya kepada publik.

4. Pemerintah daerah dengan ukuran legislatif yang banyak seharusnya mampu meningkatkan kinerjanya. Jika pemerintah daerah dengan anggota DPRD yang banyak namun kinerjanya semakin menurun, maka pemerintah daerah tersebut harus melakukan evaluasi terhadap para jajaran legislatifnya guna melakukan perbaikan kinerja ke depannya.

5. Hasil pemeriksaan audit BPK terkait temuan audit menunjukkan bahwa pemerintah daerah harus lebih mawas diri dalam mengelola keuangan daerahnya karena buruknya kepatuhan terhadap peraturan perundangan-undangan mempengaruhi akan kinerja keuangan daerah. Sedangkan opini audit belum cukup untuk menjelaskan keterkaitannya dengan kinerja keuangan pemerintah daerah. Hal ini menunjukkan bahwa opini audit suatu pemerintah daerah yang baik belum tentu menunjukkan kinerja keuangan pemerintah daerah tersebut akan baik pula.

\section{KESIMPULAN DAN SARAN}

Hasil penelitian ini menemukan bahwa Ukuran pemerintah daerah; tingkat kekayaan daerah; dan opini audit tidak berpengaruh signifikan terhadap kinerja keuangan pemerintah daerah di Sulsel. Sedangkan tingkatketergantungan pada pemerintah pusat dan jumlah belanja daerah berpengaruh positif signifikan terhadap kinerja keuangan pemerintah daerah, serta ukuran legislatif dan temuan audit berpengaruh negatif signifikan terhadap kinerja keuangan pemerintah daerah di Sulsel

Penelitian ini hanya menggunakan tujuh variabel yang mempengaruhi kinerja keuangan pemda, disarankan kepada peneliti selanjutnya untuk menambah varabel lain yang dapat mempengaruhi peningkatan kinerja keuangan pemda Sulawesi Selatan.

\section{DAFTAR RUJUKAN}

Azhar, Muhammad Karya Satya. 2008. Analisa Kinerja Keuangan Pemerintah Daerah Kabupaten/Kota Sebelum dan Setelah Otonomi Daerah. Tesis. Program Pascasarjana Universitas Sumatera Utara. 
Badan Pemeriksaan Keuangan Republik Indonesia.Ikhtisar Hasil Pemeriksaan Semester 1 Tahun 2012.http://www/bpk.go.id_diakses pada 26 Mei 2013.

Badan Pemeriksaan Keuangan Republik Indonesia.Ikhtisar Hasil Pemeriksaan Semester 2 Tahun 2012.http://www/bpk.go.id_diakses pada 26 Mei 2013.

Bastian, Indra. 2006. Akuntansi Sektor Publik. Jakarta: Erlangga.

Bisma, I Dewa Gde., Susanto, Hery. 2010. 'Evaluasi Kinerja Keuangan Daerah Pemerintah Provinsi Nusa Tenggara Barat Tahun Anggaran 2003-2007. Jurnal GaneC Swara Edisi Khusus Vol.4 No.3, Desember. Universitas Mataram.

Faud,Mohamad Ramly,2013,Analisis Kinerja Pengelolaan Keuangan Daerah Kota Ambon,Jurnal Akmen STIE Nobel,Vol 10 Desember 2013

Dirjen Perimbangan Keuangan Pemerintah Daerah.Laporan Realisasi APBD 2011. www.djpk.depkeu.go.id diakses pada 21 Juni 2013.

Hadi, Abdul, Hendri, Sapto, dan Inapty, Biana Adha. 2009. Analisa Pengaruh Pertumbuhan Ekonomi, Pendapatan Asli Daerah, Dana Alokasi Umum, dan Dana Alokasi Khusus Terhadap Pengalokasian Belanja Modal. Penelitian keuangan akuntansi sektor publik II Badan Litbang Departemen dalam Negeri, Bidakara, 2-3 Juni 2009.

Halim, Abdul. 2001. Manajemen Keuangan Daerah. Yogyakarta: UPP YKPN.

Hamzah, Ardi. 2008. Analisa Kinerja Keuangan terhadap Pertumbuhan Ekonomi, Pengangguran, dan Kemiskinan: Pendekatan Analisis Jalur (Studi pada 29 Kabupaten dan 9 Kota di Propinsi Jawa Timur Periode 2001-2006). Jurnal. Universitas Trunojoyo Madura.

Mustikarini, Widya Astuti., Fitriasari, Debby. 2012. 'Pengaruh Karakteristik Pemerintah Daerah dan Temuan Audit BPK terhadap Kinerja Pemerintah Daerah Kabupaen/Kota di Indonesia Tahun Anggaran 2007'. Simposium Nasional Akuntansi XV: Banjarmasin.
Ningsih, Ayu Tutia. 2011. Analisis Faktor Keuangan dan Faktor Lingkungan yang Mempengaruhi Kinerja Keuangan Pemerintah Daerah Universitas Sebelas Maret Surakarta.

Patrick, P. A. 2007. The Determinant of Organizational Inovativeness: The Adoption of GASB 34 in Pennsylvania Local Government. Unpublished Ph.D Dissertation.

Pennsylvania:ThePennsylvaniaStateUn iversity.

Prud'homme, Remy. 1995. 'The Dangers of Decentralization'. The World Bank Research Observer 10(2): 201-220.

Sekaran, Uma dan Bougie, Roger. 2010. Research Methods for Business-A Skill Building Approach-5th Edition. United Kingdom: John Wiley\&Sons Ltd.

Suhardjanto, Djoko., Rusmin, Mandasari., Putriesti., dan Brown, Alistair. 2010. 'Mandatory Disclosure Compliance and Local Government Charactheristics: Evidence From Indonesian Municipalities'. Journal Public Policy January 2010

Suhardjanto, Djoko., Yulianingtyas, Rena Rukmita. 2011. 'Pengaruh Karakteristik Pemerintah Daerah terhadap Kepatuhan Pengungkapan Wajib dalam Laporan Keuangan Pemerintah Daerah (Studi Empiris pada Kabupaten/Kota di Indonesia). Jurnal Akuntansi \& Auditing. Volume 8/No.1/November 20011: 1-194.

Sumarjo, Hendro. 2010. Pengaruh Karakteristik Pemerintah Daerah terhadap Kinerja Keuangan Pemerintah Daerah (Studi Empiris pada Pemerintah Daerah Kabupaten/Kota di Indonesia).Skripsi.Universitas Sebelas Maret Surakarta.

Undang-Undang No.15 Tahun 2004 tentang Pemeriksaan Pengelolaan dan Tanggung Jawab Keuangan Negara.

Undang-Undang No.32 Tahun 2004 tentang Pemerintahan Daerah.

Undang-Undang No.33 Tahun 2004 tentang Perimbangan Keuangan antara Pemerintah Pusat dan Pemerintah Daerah. 